\title{
Some forms of N-closed Maps in supra Topological spaces
}

\author{
L.Vidyarani and M.Vigneshwaran \\ Department of Mathematics Kongunadu Arts and Science College Coimbatore,Tamil Nadu, India.
}

\begin{abstract}
In this paper, we introduce the concept of $N$-closed maps and we obtain the basic properties and their relationships with other forms of $N$-closed maps in supra topological spaces.

Keywords: supra $N$-closed map, almost supra $N$-closed map, strongly supra $N$-closed map.
\end{abstract}

\section{Introduction:}

In 1983, A.S.Mashhour et al [4] introduced the supra topological spaces and studied, continuous functions and $\mathrm{s}^{*}$ continuous functions. T.Noiri and O.R.Syed[5] introduced supra b-open sets and b-continuity on topological spaces.

In this paper, we introduce the concept of supra $\mathrm{N}$-closed maps and study its basic properties. Also we introduce the concept of almost supra $\mathrm{N}$-closed maps and strongly supra $\mathrm{N}$-closed maps and investigate their properties in supra topological spaces.

Definition 2.1[4]

\section{Preliminaries:}

A subfamily $\mu$ of $X$ is said to be supra topology on $X$ if

i) $X, \phi \in \mu$

ii)If $A_{i} \in \mu \forall i \in j$ then $\cup A_{i} \in \mu$. (X, $\left.\mu\right)$ is called supra topological space.

The element of $\mu$ are called supra open sets in $(X, \mu)$ and the complement of supra open set is called supra closed sets and it is denoted by $\mu^{\mathrm{c}}$.

\section{Definition 2.2[4]}

The supra closure of a set $\mathrm{A}$ is denoted by $\mathrm{cl}^{\mu}(\mathrm{A})$, and is defined as supra $\operatorname{cl}(\mathrm{A})=\cap\{\mathrm{B}: \mathrm{B}$ is supra closed and $\mathrm{A} \subseteq \mathrm{B}\}$.

The supra interior of a set $A$ is denoted by int ${ }^{\mu}(A)$, and is defined as supra $\operatorname{int}(\mathrm{A})=\cup\{\mathrm{B}: \mathrm{B} \quad$ is supra open and $\mathrm{A} \supseteq \mathrm{B}\}$.

Definition 2.3[4]

Let $(X, \tau)$ be a topological space and $\mu$ be a supra topology on $X$. We call $\mu$ a supra topology associated with $\tau$, if $\tau \subseteq \mu$.

\section{Definition 2.4[3]}

Let $(X, \mu)$ be a supra topological space. A set $A$ of $X$ is called supra semi- open set, if $A \subseteq$ $\mathrm{cl}^{\mu}\left(\right.$ int $\left.^{\mu}(A)\right)$. The complement of supra semi-open set is supra semi-closed set.

\section{Definition 2.5[1]}

Let $(X, \mu)$ be a supra topological space. A set $A$ of $X$ is called supra $\alpha$-open set, if $A \subseteq \operatorname{int}^{\mu}\left(\mathrm{cl}^{\mu}\right.$ (int $\left.{ }^{\mu}(\mathrm{A})\right)$ ). The complement of supra $\alpha$-open set is supra $\alpha$-closed set.

\section{Definition 2.6[5]}

Let $(X, \mu)$ be a supra topological space. A set A of X is called supra $\Omega$ closed set, if scl ${ }^{\mu}(\mathrm{A}) \subseteq$ int $^{\mu}$ (U),whenever $\mathrm{A} \subseteq \mathrm{U}, \mathrm{U}$ is supra open set. The complement of the supra $\Omega$ closed set is supra $\Omega$ open set.

\section{Definition 2.7[5]}

The supra $\Omega$ closure of a set A is denoted by $\Omega \mathrm{cl}^{\mu}(\mathrm{A})$, and defined as is supra $\Omega$ closed and $\mathrm{A} \subseteq \mathrm{B}\}$.

The supra $\Omega$ interior of a set $\mathrm{A}$ is denoted by $\Omega$ int ${ }^{\mu}$ (A), and defined as is supra $\Omega$ open and $\mathrm{A} \supseteq \mathrm{B}$ \}.

\section{Definition 2.8[6]}

Let $(X, \mu)$ be a supra topological space . A set $A$ of $X$ is called supra regular open if $A=\operatorname{int}^{\mu}\left(c^{\mu}(A)\right)$ and supra regular closed if $\mathrm{A}=\mathrm{cl}^{\mu}\left(\right.$ int $\left.^{\mu}(\mathrm{A})\right)$. 


\section{Definition 2.9[7]}

Let $(X, \mu)$ be a supra topological space . A set A of $X$ is called supra $N$-closed set if $\Omega$ cl ${ }^{\mu}(A) \subseteq U$, whenever $\mathrm{A} \subseteq \mathrm{U}, \mathrm{U}$ is supra $\alpha$ open set. The complement of supra $\mathrm{N}$-closed set is supra $\mathrm{N}$-open set.

\section{Definition 2.10[7]}

The supra $\mathrm{N}$ closure of a set $\mathrm{A}$ is denoted by $\mathrm{Ncl}^{\mu}(\mathrm{A})$, and defined as $\mathrm{Ncl}^{\mu}(\mathrm{A})=\cap\{\mathrm{B}: \mathrm{B}$ is supra $\mathrm{N}$ closed and $\mathrm{A} \subseteq \mathrm{B}\}$.

The supra $\mathrm{N}$ interior of a set $\mathrm{A}$ is denoted by $\operatorname{Nint}^{\mu}(\mathrm{A})$, and defined as is supra $\mathrm{N}$ open and $\mathrm{A} \supseteq \mathrm{B}\}$.

\section{Definition 2.11[7]}

Let $(\mathrm{X}, \tau)$ and $(\mathrm{Y}, \sigma)$ be two topological spaces and $\mu$ be an associated supra topology with $\tau$. A function $\mathrm{f}:(\mathrm{X}, \tau) \rightarrow(\mathrm{Y}, \sigma)$ is called supra $\mathrm{N}$-continuous closed in $(\mathrm{X}, \tau)$ for every supra closed set $\mathrm{V}$ of $(\mathrm{Y}, \sigma)$. function if $\mathrm{f}^{-1}(\mathrm{~V})$ is supra $\mathrm{N}$ -

\section{Definition 2.12[7]}

Let $(\mathrm{X}, \tau)$ and $(\mathrm{Y}, \sigma)$ be two topological spaces and $\mu$ be an associated supra topology with $\tau$. A function $\mathrm{f}:(\mathrm{X}, \tau) \rightarrow(\mathrm{Y}, \sigma)$ is called supra N-irresolute if $\mathrm{f}^{-1}(\mathrm{~V})$ is supra $\mathrm{N}$-closed in $(\mathrm{X}, \tau)$ for every supra $\mathrm{N}$-closed set $\mathrm{V}$ of $(\mathrm{Y}, \sigma)$.

Notations: Throughout this paper $O^{\mu}(\tau)$ represents supra open set of $(\mathrm{X}, \tau)$ and $N^{\mu} O(\tau)$ represents supra $\mathrm{N}$-open set of $(\mathrm{X}, \tau)$.

\section{Definition 3.1}

\section{Supra N-Closed Maps}

A map $\mathrm{f}:(\mathrm{X}, \tau) \rightarrow(\mathrm{Y}, \sigma)$ is called supra $\mathrm{N}$-closed map(resp. supra $\mathrm{N}$-open) if for every supra closed(resp. supra open) F of $\mathrm{X}, \mathrm{f}(\mathrm{F})$ is supra $\mathrm{N}$-closed(resp. supra $\mathrm{N}$-open) in $\mathrm{Y}$.

\section{Theorem 3.2}

\section{Proof}

Every supra closed map is supra $\mathrm{N}$-closed map.

Let $\mathrm{f}:(\mathrm{X}, \tau) \rightarrow(\mathrm{Y}, \sigma)$ be supra closed map. Let $\mathrm{V}$ be supra closed set in $\mathrm{X}$, Since $\mathrm{f}$ is supra closed map then $f(V)$ is supra closed set in Y. We know that every supra closed set is supra N-closed, then $f(V)$ is supra Nclosed in $\mathrm{Y}$. Therefore $\mathrm{f}$ is supra $\mathrm{N}$-closed map.

The converse of the above theorem need not be true. It is shown by the following example.

\section{Example 3.3}

Let $\mathrm{X}=\mathrm{Y}=\{\mathrm{a}, \mathrm{b}, \mathrm{c}\}$ and $\tau=\{\mathrm{X}, \varphi,\{\mathrm{a}\},\{\mathrm{b}, \mathrm{c}\}\}, \sigma=\{\mathrm{Y}, \varphi,\{\mathrm{a}\}\}$.

$\mathrm{f}:(\mathrm{X}, \tau) \rightarrow(\mathrm{Y}, \sigma)$ be the function defined by $\mathrm{f}(\mathrm{a})=\mathrm{b}, \mathrm{f}(\mathrm{b})=\mathrm{c}, \mathrm{f}(\mathrm{c})=\mathrm{a}$. Here $\mathrm{f}$ is supra N-closed map but not supra closed map, since $V=\{b, c\}$ is closed in $X$ but $f(\{b, c\})=\{a, c\}$ is supra N-closed set but not supra closed in Y.

\section{Theorem 3.4}

Proof

A map $\mathrm{f}:(\mathrm{X}, \tau) \rightarrow(\mathrm{Y}, \sigma)$ is supra N-closed iff $\mathrm{f}\left(\mathrm{cl}^{\mu}(\mathrm{V})\right)=\mathrm{Ncl}^{\mu}(\mathrm{f}(\mathrm{V}))$

Suppose $\mathrm{f}$ is supra $\mathrm{N}$-closed map. Let $\mathrm{V}$ be supra closed set in $(\mathrm{X}, \tau)$. Since $\mathrm{V}$ is supra closed , $\mathrm{cl}^{\mu}(\mathrm{V})=\mathrm{V}$. $f(V)$ is supra N-closed in $(Y, \sigma)$. Since $f$ is supra N-closed map, then $f\left(c l^{\mu}(V)\right)=f(V)$. Since $f(V)$ is supra N-closed, we have $\mathrm{Ncl}^{\mu}(\mathrm{f}(\mathrm{V}))=\mathrm{f}(\mathrm{V})$. Hence $\mathrm{f}\left(\mathrm{cl}^{\mu}(\mathrm{V})\right)=\mathrm{Ncl}^{\mu}(\mathrm{f}(\mathrm{V}))$

Conversly, suppose $f\left(c^{\mu}(V)\right)=N c l^{\mu}(f(V))$. Let $V$ be supra closed set in $(X, \tau)$, then $\mathrm{cl}^{\mu}(V)=V$. since $f$ is a mapping, $f(V)$ is in $(Y, \sigma)$ and we have $f\left(c^{\mu}(V)\right)=f(V)$. Since $f\left(c^{\mu}(V)\right)=N c l^{\mu}(f(V))$, we have $f(V)=\operatorname{Ncl}^{\mu}(f(V))$, implies $\mathrm{f}(\mathrm{V})$ is supra $\mathrm{N}$-closed in $(\mathrm{Y}, \sigma)$. Therefore $\mathrm{f}$ is supra $\mathrm{N}$-closed map.

Theorem 3.5

Proof

A map $\mathrm{f}:(\mathrm{X}, \tau) \rightarrow(\mathrm{Y}, \sigma)$ is supra $\mathrm{N}$-open iff $\mathrm{f}\left(\operatorname{int}^{\mu}(\mathrm{V})\right)=\operatorname{Nint}^{\mu}(\mathrm{f}(\mathrm{V}))$

Suppose $f$ is supra $N$-open map. Let $V$ be supra open set in $(X, \tau)$. Since $V$ is supra open, $\operatorname{int}^{\mu}(V)=V, f(V)$ is supra $N$-open in $(Y, \sigma)$. Since $f$ is supra N-open map, Therefore $f\left(\operatorname{int}^{\mu}(V)\right)=f(V)$. Since $f(V)$ is supra N-open, we have $\operatorname{Nint}^{\mu}(f(V))=f(V)$. Hence $f\left(\operatorname{int}^{\mu}(V)\right)=\operatorname{Nint}^{\mu}(f(V))$

Conversly, suppose $f\left(\operatorname{int}^{\mu}(V)\right)=\operatorname{Nint}^{\mu}(f(V))$. Let $V$ be a supra open set in $(X, \tau)$, then int ${ }^{\mu}(V)=V$. Since $f$ is a mapping, $f(V)$ is in $(Y, \sigma)$ and we have $f\left(\operatorname{int}^{\mu}(V)\right)=f(V)$. Since $f\left(\operatorname{int}^{\mu}(V)\right)=\operatorname{Nint}^{\mu}(f(V))$, we have $f(V)=$ $\operatorname{Nint}^{\mu}(f(V))$, implies $f(V)$ is supra $N$-open in $(Y, \sigma)$. Therefore $f$ is supra $N$-open map. 
If $\mathrm{f}:(\mathrm{X}, \tau) \rightarrow(\mathrm{Y}, \sigma)$ is supra $\mathrm{N}$-closed map and $\mathrm{g}:(\mathrm{Y}, \sigma) \rightarrow(\mathrm{Z}, \mathrm{v})$ is supra $\mathrm{N}$-closed map then its composite need not be supra $\mathrm{N}$-closed map in general and this is shown by the following example.

\section{Example 3.7}

Let $X=Y=Z=\{a, b, c\}$ and $\tau=\{X, \varphi,\{a\}\{b, c\}\}, \sigma=\{Y, \varphi,\{a\}\}$. $\mathrm{v}=\{\mathrm{Z}, \varphi\{\mathrm{a}\},\{\mathrm{b}\},\{\mathrm{a}, \mathrm{b}\},\{\mathrm{b}, \mathrm{c}\}\}$. $\mathrm{f}:(\mathrm{X}, \tau) \rightarrow(\mathrm{Y}, \sigma)$ be the function defined by $\mathrm{f}(\mathrm{a})=\mathrm{b}, \mathrm{f}(\mathrm{b})=\mathrm{c}, \mathrm{f}(\mathrm{c})=\mathrm{a}$. and $\mathrm{g}:(\mathrm{Y}, \sigma) \rightarrow(\mathrm{Z}, \mathrm{v})$ be the function defined by $g(a)=b, g(b)=c, g(c)=a$. Here $f$ and $g$ is supra $N$-closed map, but its composition is not $\mathrm{N}$-closed $\mathrm{map}$, since $\mathrm{g}$ of $\{\mathrm{b}, \mathrm{c}\}=\{\mathrm{a}, \mathrm{b}\}$ is $\mathrm{n}$ ot $\mathrm{N}$-closed in $(\mathrm{Z}, \mathrm{v})$.

\section{Theorem:3.8}

If $\mathrm{f}:(\mathrm{X}, \tau) \rightarrow(\mathrm{Y}, \sigma)$ is supra closed map and $\mathrm{g}:(\mathrm{Y}, \sigma) \rightarrow(\mathrm{Z}, \mathrm{v})$ is supra $\mathrm{N}$-closed map then the composition gof is supra $\mathrm{N}$-closed map.

\section{Proof}

Let $V$ be supra closed set in $X$. Since $f$ is a supra closed map, $f(V)$ is supra closed set in Y. Since $g$ is supra Nclosed map, $\mathrm{g}(\mathrm{f}(\mathrm{V}))$ is supra $\mathrm{N}$-closed in $\mathrm{Z}$. This implies gof is supra N-closed map.

\section{Definition 4.1}

\section{Almost supra N-closed map and strongly supra N-closed map .}

A map $\mathrm{f}:(\mathrm{X}, \tau) \rightarrow(\mathrm{Y}, \sigma)$ is said to be almost supra $\mathrm{N}$-closed map if for every supra regular closed set $F$ of $X, f(F)$ is supra $N$-closed in $Y$.

\section{Definition 4.2}

A map $\mathrm{f}:(\mathrm{X}, \tau) \rightarrow(\mathrm{Y}, \sigma)$ is said to be strongly supra $\mathrm{N}$-closed map if for every supra $\mathrm{N}$-closed set $\mathrm{F}$ of $\mathrm{X}, \mathrm{f}(\mathrm{F})$ is supra $\mathrm{N}$-closed in $\mathrm{Y}$.

\section{Theorem 4.3}

Every strongly supra N-closed map is supra N-closed map.

Proof

Let V be supra closed set in X. Since every supra closed set is supra N-closed set, then V is supra N-closed in $X$. Since $\mathrm{f}$ is strongly supra N-closed map, $\mathrm{f}(\mathrm{V})$ is supra $\mathrm{N}$-closed set in Y. Therefore $\mathrm{f}$ is supra N-closed map.

\section{Example 4.4}

The converse of the above theorem need not be true. It is shown by the following example.

Let $\mathrm{X}=\mathrm{Y}=\{\mathrm{a}, \mathrm{b}, \mathrm{c}\}$ and $\tau=\{\mathrm{X}, \varphi,\{\mathrm{a}\}\}, \sigma=\{\mathrm{Y}, \varphi,\{\mathrm{b}\},\{\mathrm{a}, \mathrm{b}\},\{\mathrm{b}, \mathrm{c}\}\}$

$\mathrm{f}:(\mathrm{X}, \tau) \rightarrow(\mathrm{Y}, \sigma)$ be the function defined by $\mathrm{f}(\mathrm{a})=\mathrm{b}, \mathrm{f}(\mathrm{b})=\mathrm{c}, \mathrm{f}(\mathrm{c})=\mathrm{a}$. Here $\mathrm{f}$ is supra N-closed map but not strongly supra $\mathrm{N}$-closed map, since $\mathrm{V}=\{\mathrm{a}, \mathrm{b}\}$ is supra $\mathrm{N}$-closed set in $\mathrm{X}$, but $\mathbf{f}(\{\mathrm{a}, \mathrm{b}\})=$ $\{b, c\}$ is not a supra N-closed set in Y.

\section{Theorem 4.5}

\section{Proof}

Every supra $\mathrm{N}$-closed map is almost supra $\mathrm{N}$-closed map.

Let $\mathrm{V}$ be a supra regular closed set in $\mathrm{X}$. We know that every supra regular closed set is supra closed set. Therefore V is supra closed set in X. Since $f$ is supra N-closed map, $f(V)$ is supra N-closed set in Y. Therefore $\mathrm{f}$ is almost supra $\mathrm{N}$-closed map.

\section{Example 4.6}

The converse of the above theorem need not be true. It is shown by the following example.

Let $X=Y=\{a, b, c\}$ and $\tau=\{X, \varphi,\{a\},\{b\},\{a, b\},\{b, c\}\}$,

$\sigma=\{Y, \varphi$, $\{a\},\{c\},\{a, c\}\} . f:(X, \tau) \rightarrow(Y, \sigma)$ be a function defined by $f(a)=c, f(b)=b, f(c)=a$. Here $f$ is a $1 \mathrm{mos} t$ supra $\mathrm{N}$ - closed map but it is not supra $\mathrm{N}$-closed map, since $\mathrm{V}=\{\mathrm{a}, \mathrm{c}\}$ is supra closed set in $\mathrm{X}$ but $\mathbf{f}(\{\mathrm{a}, \mathrm{c}\})=$ $\{a, c\}$ is not supra $\quad \mathrm{N}$-closed set in $\mathrm{Y}$.

Theorem 4.7

Proof

Every strongly supra N-closed map is almost supra N-closed map.

Let $\mathrm{V}$ be supra regular closed set in $\mathrm{X}$. We know that every supra regular closed set is supra closed set and every supra closed set is supra $\mathrm{N}$-closed set. Therefore $\mathrm{V}$ is supra $\mathrm{N}$-closed set in $\mathrm{X}$. Since $\mathrm{f}$ is strongly supra $\mathrm{N}$-closed map, $\mathrm{f}(\mathrm{V})$ is supra $\mathrm{N}$-closed set in $\mathrm{Y}$. Therefore $\mathrm{f}$ is almost supra $\mathrm{N}$-closed map.

\section{Example 4.8}

The converse of the above theorem need not be true. It is shown by the following example.

Let $\mathrm{X}=\mathrm{Y}=\{\mathrm{a}, \mathrm{b}, \mathrm{c}\}$ and $\tau=\{\mathrm{X}, \varphi,\{\mathrm{a}\},\{\mathrm{c}\},\{\mathrm{a}, \mathrm{c}\}\}, \sigma=\{\mathrm{Y}, \varphi,\{\mathrm{a}\},\{\mathrm{b}\},\{\mathrm{a}, \mathrm{b}\},\{\mathrm{b}, \mathrm{c}\}\} . \mathrm{f}:(\mathrm{X}, \tau) \rightarrow(\mathrm{Y}, \sigma)$ be the function defined by $f(a)=b, f(b)=c, f(c)=a$. Here $f$ is a lmost supra $N$ - closed map but it is not strongly supra N-closed map, since $V=\{a\}$ is supra $N$-closed in $X$ but $f(\{a\})=\{b\}$ is not supra $\quad N$ closed set in Y.

\section{Theorem:4.9}


If $\mathrm{f}:(\mathrm{X}, \tau) \rightarrow(\mathrm{Y}, \sigma)$ is strongly supra $\mathrm{N}$-closed map and $\mathrm{g}:(\mathrm{Y}, \sigma) \rightarrow(\mathrm{Z}, \mathrm{v})$ is strongly supra $\mathrm{N}$-closed map then its composition gof is strongly supra $\mathrm{N}$-closed map.

Proof

Let $\mathrm{V}$ be supra $\mathrm{N}$-closed set in $\mathrm{X}$. Since $\mathrm{f}$ is strongly supra $\mathrm{N}$-closed, then $\mathrm{f}(\mathrm{V})$ is supra $\mathrm{N}$-closed in $\mathrm{Y}$. Since $g$ is strongly supra N-closed, then $g(f(V))$ is supra N-closed in $\mathrm{Z}$. Therefore gof is strongly supra N-closed map.

\section{Theorem 4.10}

If $\mathrm{f}:(\mathrm{X}, \tau) \rightarrow(\mathrm{Y}, \sigma)$ is almost supra $\mathrm{N}$-closed map and $\mathrm{g}:(\mathrm{Y}, \sigma) \rightarrow(\mathrm{Z}, \mathrm{v})$ is strongly supra $\mathrm{N}$-closed map then its composite gof is almost supra $\mathrm{N}$-closed map.

\section{Proof}

Let $V$ be supra regular closed set in $X$. Since $f$ is almost supra $N$-closed, then $f(V)$ is supra N-closed set in $Y$. Since $g$ is strongly supra $\mathrm{N}$-closed,then $\mathrm{g}(\mathrm{f}(\mathrm{V}))$ is supra $\mathrm{N}$-closed in $\mathrm{Z}$. Therefore gof is almost supra $\mathrm{N}$-closed map.

\section{Theorem 4.11}

Let $\mathrm{f}:(\mathrm{X}, \tau) \rightarrow(\mathrm{Y}, \sigma)$ and $\mathrm{g}:(\mathrm{Y}, \sigma) \rightarrow(\mathrm{Z}, \mathrm{v})$ be two mappings such that their composition gof: $(\mathrm{X}, \tau) \rightarrow(\mathrm{Z}, \mathrm{v})$ be a supra $\mathrm{N}$-closed mapping then the following statements are true:

(i) If $\mathrm{f}$ is supra continuous and surjective then $\mathrm{g}$ is supra $\mathrm{N}$-closed map

Proof

(ii) If $\mathrm{g}$ is supra $\mathrm{N}$-irresolute and injective then $\mathrm{f}$ is supra $\mathrm{N}$-closed map.

i) Let $\mathrm{V}$ be a supra closed set of $(Y, \sigma)$. Since $f$ is supra continuous $f^{1}(V)$ is supra closed set in $(X, \tau)$. Since gof is supra N-closed map, We have $($ gof $)\left(f^{1}(V)\right)$ is supra N-closed in $(Z, v)$. Therefore $g(V)$ is supra $\mathrm{N}$-closed in $(\mathrm{Z}, \mathrm{v})$, since $\mathrm{f}$ is surjective. Hence $\mathrm{g}$ is supra $\mathrm{N}$-closed map.

ii) Let $\mathrm{V}$ be supra closed set of $(\mathrm{X}, \tau)$. Since gof is supra $\mathrm{N}$-closed, we have $\operatorname{gof}(\mathrm{V})$ is supra $\mathrm{N}$-closed in $(\mathrm{Z}, \mathrm{v})$. Since $\mathrm{g}$ is injective and supra $\mathrm{N}$-irresolute $\quad \mathrm{g}^{-1}(\mathrm{gof}(\mathrm{V})$ is supra $\mathrm{N}$-closed in $(\mathrm{Y}$, $\sigma)$. Therefore $f(V)$ is supra $N$-closed in $\quad(Y, \sigma)$. Hence $f$ is supra $N$-closed map.

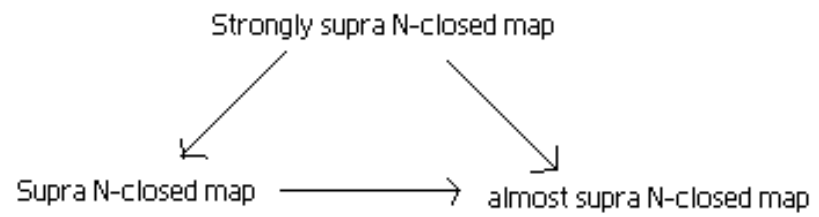

Definition:5.1

\section{Applications}

A supra topological space $(\mathrm{X}, \tau)$ is $T_{N}^{\mu}-$ space if every supra $\mathrm{N}$-closed set is supra closed in $(\mathrm{X}, \tau)$.

\section{Theorem:5.2}

Let $(\mathrm{X}, \tau)$ be a supra topological space then

(i) $O^{\mu}(\tau) \subseteq N^{\mu} O(\tau)$

(ii) A space $(\mathrm{X}, \tau)$ is $T_{N}^{\mu}-$ space iff $O^{\mu}(\tau)=N^{\mu} O(\tau)$

Proof

(i) Let A be supra open set, then X-A is supra closed set. We know that every closed set is N-closed. Therefore X-A is N-closed, implies A is N-open. Hence $O^{\mu}(\tau) \subseteq N^{\mu} O(\tau)$

(ii) Let $(\mathrm{X}, \tau)$ be $T_{N}^{\mu}$-space. Let $\mathrm{A} \in N^{\mu} O(\tau)$, then X-A is N-closed, by hypothesis X-A is closed and therefore $\mathrm{A} \in O^{\mu}(\tau)$. Hence we have $O^{\mu}(\tau)=N^{\mu} O(\tau)$. Conversely the proof is obvious

\section{Theorem:5.3}

If $(\mathrm{X}, \tau)$ is $T_{N}^{\mu}-$ space, then every singleton set of $(\mathrm{X}, \tau)$ is either supra $\alpha$-closed set or supra open set.

\section{Proof}

Suppose that for some $x \in X$, the set $\{x\}$ is not supra $\alpha$-closed set of $(X, \tau)$, then $\{x\}$ is not supra $N$-closed set in $(X, \tau)$, Since we know that every $\alpha$-closed set is supra $N$-closed set. So trivially $\{x\}^{\mathrm{c}}$ is $\mathrm{N}$-closed set. From the hypothesis $\{\mathrm{x}\}^{\mathrm{c}}$ is supra closed set in $(X, \tau)$. Therefore $\{\mathrm{x}\}$ is supra open set

\section{Theorem:5.4}


Let $\mathrm{f}:(\mathrm{X}, \tau) \rightarrow(\mathrm{Y}, \sigma)$ be supra N-closed map and $\mathrm{g}:(\mathrm{Y}, \sigma) \rightarrow(\mathrm{Z}, v)$ be supra N-closed map then their composition gof: $(\mathrm{X}, \tau) \rightarrow(\mathrm{Z}, \mathrm{v})$ is a supra $\mathrm{N}$-closed map if $(\mathrm{Y}, \sigma)$ is $T_{N}^{\mu}-$ space.

Proof

Let $\mathrm{V}$ be a supra closed set in $\mathrm{X}$. Since $\mathrm{f}$ is supra $\mathrm{N}$-closed map, then $\mathrm{f}(\mathrm{V})$ is supra $\mathrm{N}$-closed set in $\mathrm{Y}$. Since $\mathrm{Y}$ is $T_{N}^{\mu}$ - space, $\mathrm{f}(\mathrm{V})$ is supra closed set in $\mathrm{Y}$. Since $\mathrm{g}$ is supra N-closed map, we have $\mathrm{g}(\mathrm{f}(\mathrm{V}))$ is supra N-closed in $\mathrm{Z}$. Hence gof is a N-closed map.

\section{Reference}

[1] R.Devi, S.Sampathkumar and M.Caldas, "On supra $\alpha$ open sets and sa-continuous maps, General Mathematics", 16(2)(2008), 77-84

[2] P.Krishna, Dr.J.Antony Rex Rodrigo, “On R-Closed Maps and R-Homeomorphisms in Topological Spaces”, IOSR Journal of Mathematics, 4(1)(2012),13-19.

[3] N.Levine, "Semi-open sets and Semi-continuity in topological spaces", Amer.Math.,12(1991),5-13.

[4] A.S.Mashhour, A.A.Allam, F.S.Mahmoud and F.H.Khedr, "On supra topological spaces", Indian J.Pure and Appl.Math.,14(A)(1983),502-510.

[5] T.Noiri and O.R.Sayed, "On $\Omega$ closed sets and $\Omega$ s closed sets in topological spaces", Acta Math,4(2005),307-318.

[6] M.Trinita Pricilla and I.Arockiarani, "Some Stronger Forms of g $\mu$ b-continuous Functions", IOSR Journal of Engineering, 1(2), 111-117.

[7] L.Vidyarani and M.Vigneshwaran, "On Supra N-closed and sN-closed sets in Supra topological Spaces", Internatinal Journal of Mathematical Archieve, 4(2),2013,255-259. 